Ann. Biol. anim. Bioch. Biophys., 1979, 19 (5), 1455-1460.

\title{
The human ovary during puberty
}

par J. GRINSTED, Hannah PETERS

The Finsen Laboratory, The Finsen Instifute,

Strandboulevarden 49, 2100 Copenhagen, Denmark.

Summary. Changes occur in the ovaries at the time of puberty which influence the ovarian hormonal microenvironment. During childhood two main hormone-producing tissues are present in the ovaries, the antral follicles and the stroma. These are apparently similar in amount in the two ovaries during childhood. With the event of the first ovulation a third hormone-producing tissue, the corpus luteum, appears in one of the ovaries which causes the intraovarian hormonal environments to become dissimilar in the 2 ovaries.

Marked changes take place in the hypothalamus and pituitary during puberty, which influence the onset of maturity and the beginning of cyclic variations in gonadotrophic release (Dierschke ef al., 1974 ; McCann, 1976 ; Moll ef al., 1976 ; Foster and Ryan, 1979). Whether changes within the ovary also occur at the time of puberty has not been clarified yet. It has recently been reported that the two ovaries of a girl during childhood look remarkably similar, while their appearance becomes dissimilar as maturity approaches (Peters, 1979). It is likely that such a change in appearance is accompanied by a simultaneous alteration in the intraovarian hormonal environment. This communication discusses the morphological changes taking place in the ovaries during puberty and how they might lead to the formation of areas with differing hormonal potentials.

\section{The ovary during childhood}

During childhood the ovary is an active organ in which follicular growth and follicular degeneration occur simultaneously and continuously. Small, resting follicles enter the growth phase at all times during childhood, and develop to preantral and antral follicles. More follicles enter the growth phase early in childhood than later (Block, 1952 ; Peters, 1979), but more follicles reach larger antral sizes as the child grows older. The increase in the number of antral follicles causes an increase in the size of the ovary with advancing age (figs. 1 and 2). Degeneration of follicles occurs 

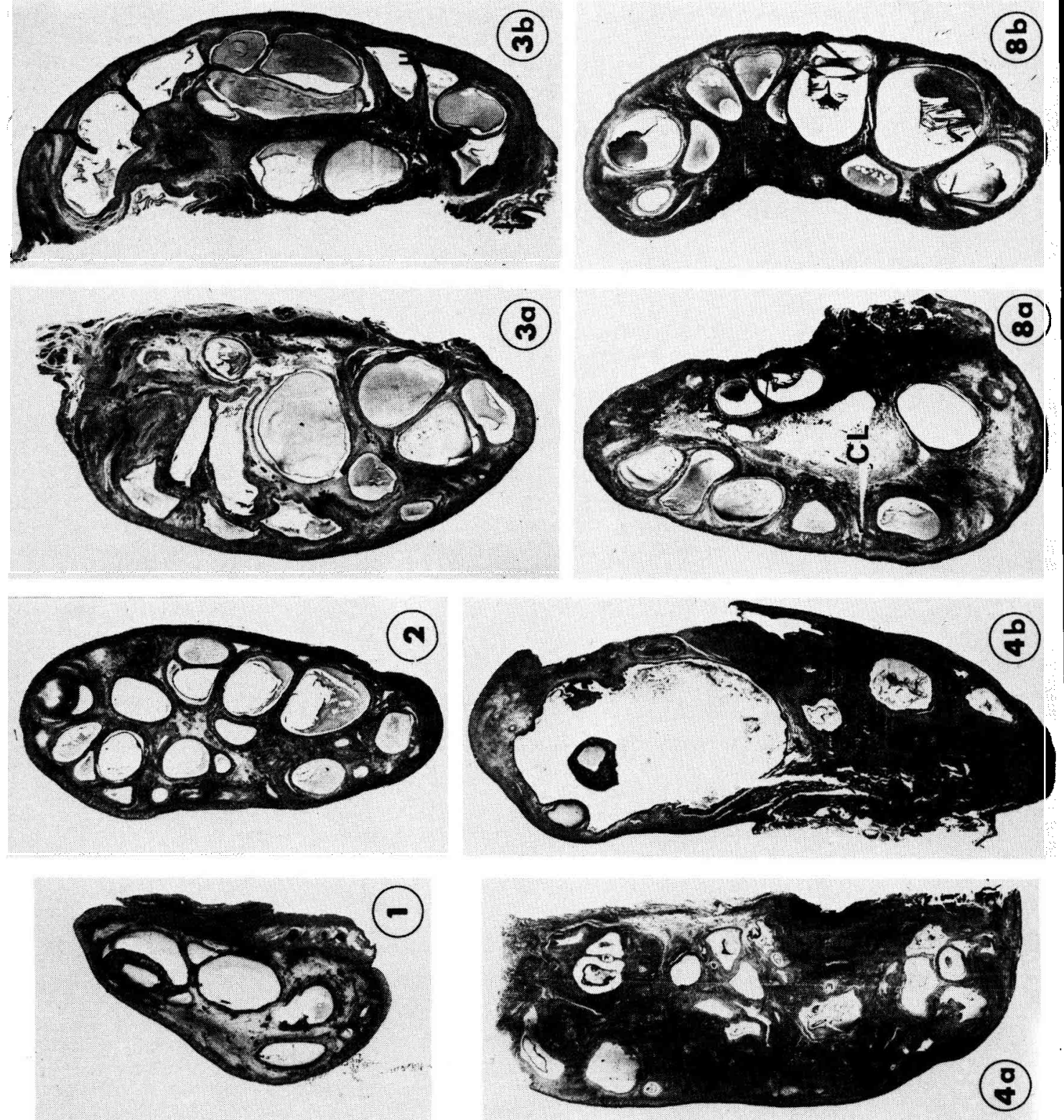

FIG. 1. - Ovary of a 4-year old child. $\times 3$.

FIG. 2. - Ovary of a 9-year old child. $\times 3$.

FIG. 3a, b. - The ovaries of a 10-year old child look similar. $\times 3$.

FIG. 4. - The ovaries of a 15-year old girl. $\Varangle .3$.

a. Ovary A contains many antral follicles up to $0.5 \mathrm{~mm}$ in diameter.

b. Ovary B contains some small antral follicles and one large one (diameter $1.6 \mathrm{~cm}$ ).

FIG. 8. - The ovaries of a 12-year old girl after the first ovulation ore dissimilar. $\times 3$.

a. The ovary consists of a large corpus leuteum (CL), follicles and stroma.

b. The ovary contains only follicles and stroma. 
throughout the growth phase, and they may deteriorate at any stage of their development. This contributes to the formation of stromal tissue. Thus the ovary contains simultaneously small resting follicles as well as growing and degenerating follicles at different stages of development. Throughout childhood and the juvenile period the two ovaries of a girl are characterized by a remarkable morphological similarity. Both are populated by a number of small and large antral follicles (fig. 3a,b). Neither of the 2 organs has an outstanding larger follicle or other characteristics that would suggest a difference between them.

\section{The ovary during puberty}

As maturity approaches the 2 ovaries often become markedly dissimilar in appearance and the characteristic uniformity of the juvenile period is lost. Though both ovaries continue to contain follicles in the growth phase, their number and size may differ considerably in the two organs. These dissimilarities were noted in a survey of the ovaries of 10 young girls who were killed in accidents. For example, we examined the ovaries of a 15-year old girl who died in an automobile accident. Her ovaries did not contain fresh or old corpora lutea ; apparently cyclic activities had not yet begun. One of her ovaries (ovary A, fig. 4a) contained many antral follicles of varying sizes up to $0.5 \mathrm{~cm}$ in diameter. Most of these showed healthy granulosa cells and a normal theca layer (fig. 5). Some were degenerating. The contralateral ovary (ovary B, fig. 4b) looked quite different. It contained several antral follicles of similar sizes as ovary $A$, but in addition it included a very large antral follicle with a diameter of $1.6 \mathrm{~cm}$. That follicle had not achieved ovulation though it had reached preovulatory size. Its wall was luteinized (fig. 6) but its oocyte had not resumed meiosis. Most antral follicles in this ovary were degenerating. Some of them had a thinner-than-normal membrana granulosa, suggesting loss of granulosa cells; others had markedly hypertrophied theca layers with large, clear cells and many capillaries (fig. 7). Comparing these 2 ovaries, one had the impression that the intraovarian hormonal milieu of these 2 ovaries could be different as one contained areas that permitted continued antral growth, while the other produced an abundance of hypertrophied theca close to a well developed capillary network.

\section{The ovary in early maturity}

When maturity begins both ovaries remain « active », i. e. in both ovaries preantral and antral follicular growth is found. After the first ovulation has taken place the ovulating ovary differs from the contralateral one as well as from a childhood ovary. It contains, in addition to small and large antral follicles, a large postovulatory structure, the corpus luteum (fig. 8a, b). After regular ovulation has been established fresh corpora lutea and those of previous cycles can be recognized. It is not uncommon to find corpora lutea of the present as well as of previous ovulations in one ovary and none in the contralateral one. Thus marked differences in the ovaries may develop: both ovaries contain growing follicles but one may contain a considerably larger amount of fresh and older lutein tissue than the other. 


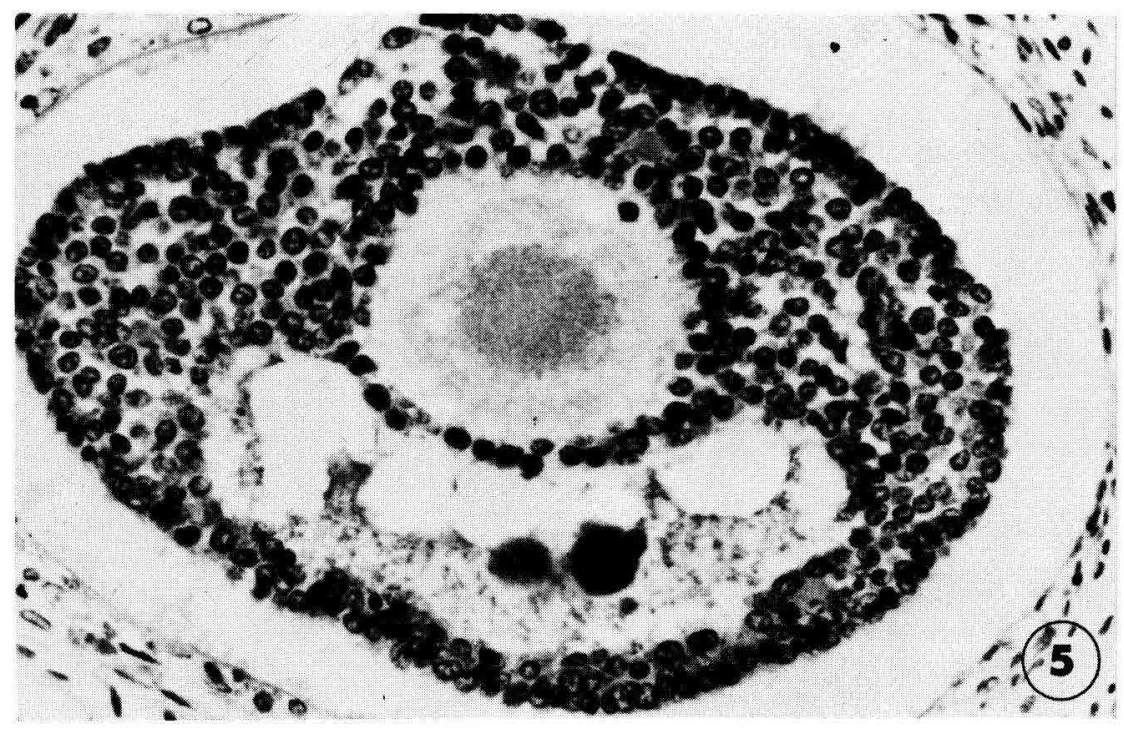

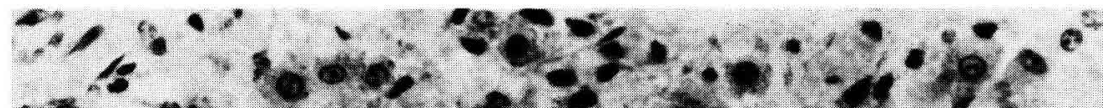

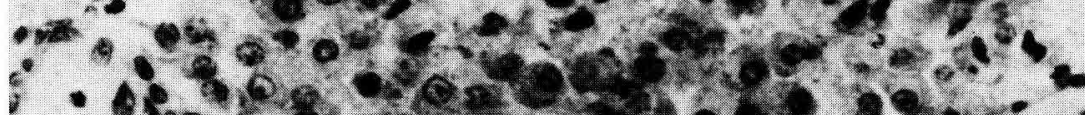

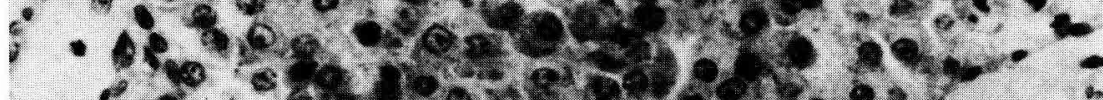

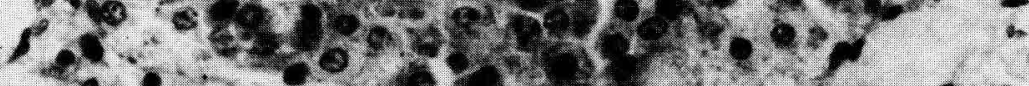

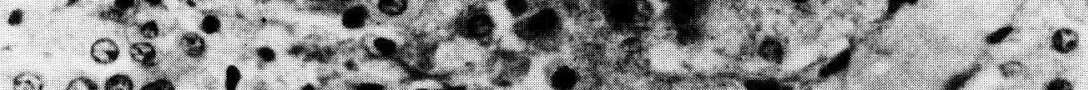

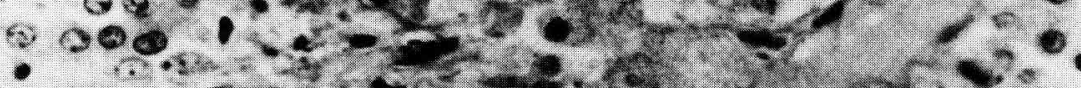

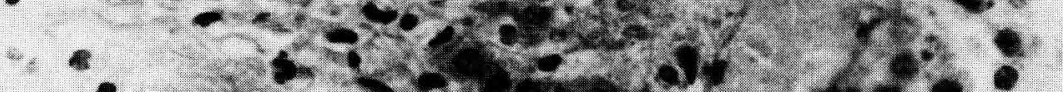

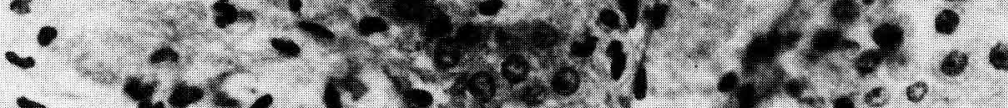

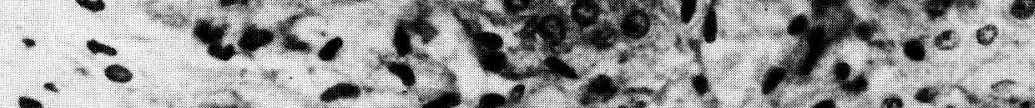

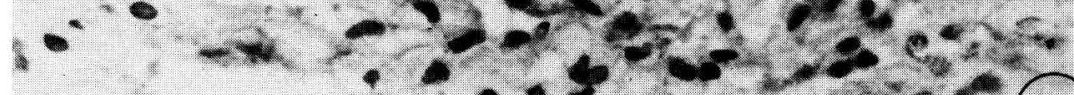

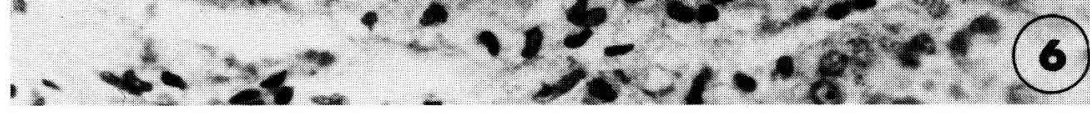

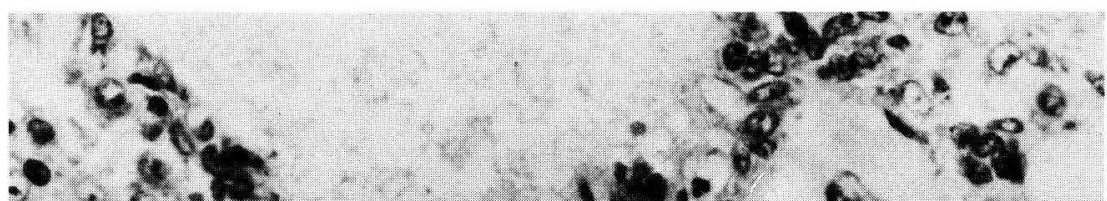

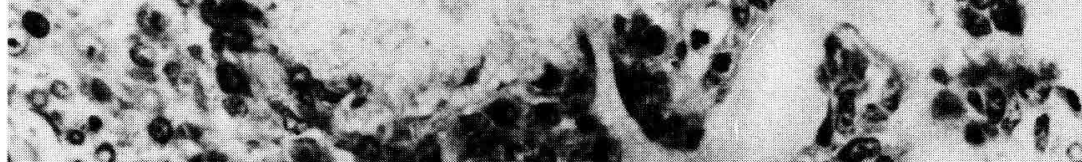

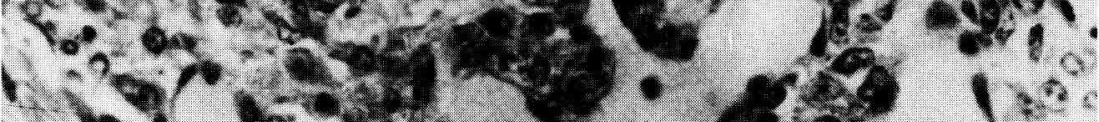

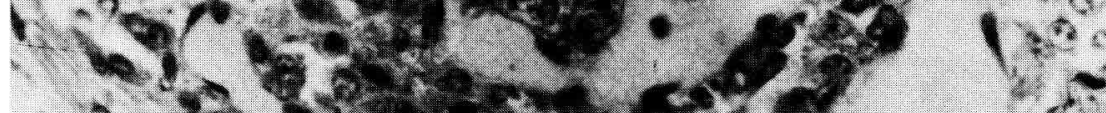

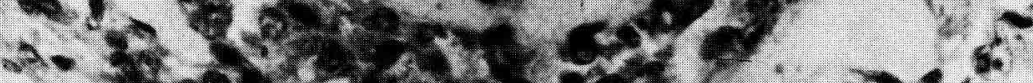

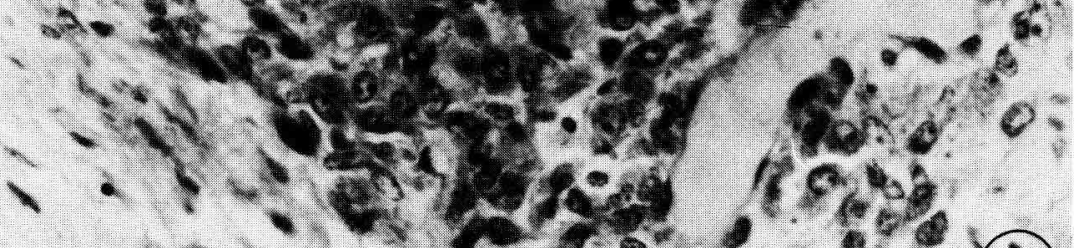

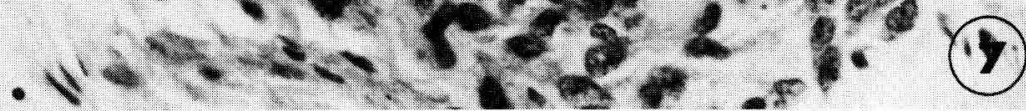




\section{Discussion.}

During childhood the number of antral follicles increases simultaneously in both ovaries. Concomitantly, the follicular degeneration contributes to the formation of the stroma. Antral follicles and stroma are hormone-producing tissues in the adult ovary. If is not known whether the childhood ovary already produces hormones, but there is circumstantial evidence of an endocrine activity in the prepubertal ovary. Oestrogen levels in blood increase with advancing age in childhood (Faiman and Winter, 1974 ; Winter et al., 1978), and urinary excretion of œstrogen rises above basal levels in later childhood (Brown et al., 1978). Brown ef al. (1978) suggested that these increasing levels of œstrogen are produced by the gonad. That this might actually be so, is suggested by the fact that antral follicles larger than $0.4 \mathrm{~cm}$ in diameter are commonly found in the childhood ovary and become more numerous after the age of 6 years (Peters et al., 1976); follicles of such size are known to produce œstrogen in the adult ovary (McNatty et al., 1975). As the rize in œstrogen levels and the increase in the number and size of antral follicles coincide in time, it is likely that the antral follicles contribute to the rising levels of circulating cestrogens during childhood. Until maturity is reached and ovulation begins, the ovaries contain two hormoneproducing tissues, the follicle and the stroma. Their occurrence and distribution are similar in the two ovaries of a prepubertal girl. However, when ovulation starts, a third hormone-producing tissue, the corpus lutum, appears in the ovary.

Thus, with the event of the first ovulation the distribution of hormone-producing tissue becomes markedly different in the two ovaries, creating intraovarian hormonal environments which are not alike in the two organs. The significance of unlike hormonal environments in the 2 ovaries of a young woman is not known yet, however, it is possible that they influence the intra-ovarian control mechanisms of follicular growth and atresia.

EEC Seminar on « Ovarian stimulation and egg quality in mammals », Luynes, France, octobre 1978.

Achnowledgements. - We would like to thank Professor L. Bjersing, Institute of Patho. logy, University of Umea, Umea, Sweden, for supplying some of the material used in the study of peripubertal and young women. For excellent technical assistance our thanks go to Inga Husum, Annelise Mohr, Tove Norager, Paul Riel and Ros Sapawi. Some of the work reported here was carried out in partial fulfillment of Euratom contract 120-73-1 Bio-DK.

FIG. 5. - Antral follicle in ovary A (shown in fig. 4a) with healthy granulosa cells. $\times .290$.

FIG. 6. - The follicle wall of the big antral follicle in ovary $B$

(shown in fig. $4 b$ ) is luteinized. $\times 290$.

FIG. 7. - Most of the degenerating follicles in ovary B (shown in fig. $4 b$ ) have hypertrophied theca layers with large clear cells and large blood vessels. $\times 290$. 
Résumé. Des changements surviennent dans les ovaires au moment de la puberté, changements qui influencent le microenvironnement hormonal ovarien. Pendant l'adolescence, deux tissus principaux producteurs d'hormone sont présents dans les ovaires, les follicules antraux et le stroma. Ceux-ci sont apparemment similaires en quantité dans les deux ovaires pendant l'adolescence. Après la première ovulation, un troisième tissu producteur d'hormone, le corpus luteum, apparaît dans un des ovaires provoquant les environnements hormonaux intraovariens qui deviennent dissemblables entre les deux ovaires.

\section{References}

BLOCK E., 1952. Quantitative morphological investigations of the follicular systems in women. Variations at different ages. Acta anat. (Basel), 14, 108-123.

BROWN J. B., HARRISON P., SMITH M. A., 1978. Oestrogen and pregnondiol excretion through childhood, menarche and first ovulation. In PARKES A. S., SHORT R. V., POTTS M., HERBERTSON M. A. Fertility regulation during adolescence, Galton Found., Cambridge, England (in press).

DIERSCHKE D. J., KARSCH F. J., WEICK R. F., WEISS G., HOTCHKISS J., KNOBIL, E., 1974. HyPOthalamic-pituitary regulation of puberty : Feedback control of gonadotropin secretion in the rhesus monkey, 104-114. In GRUMBACH M. M., GRAVE G. D., MAYER F. E. The control of onset of puberfy, John Wiley \& Sons, New York, London, Sydney, Toronto.

FAIMAN C., WINTER J. S. D., 1974. Gonadotropins and sex hormone pattern in puberty, clinical data, 32-61. In GRUMBACH M. M., GRAVE G. D., MAYER F. E. The control of onset of puberty, John Wiley \& Sons, New York, London, Sydney, Toronto.

FOSTER D. L., RYAN K., 1979. Mechanism governing onset of ovarian cyclicity at puberty in the female lamb. Ann. Biol. anim. Bioch. Biophys., 19, 1363-1380.

MCCANN S. M., 1976. Development and maturation of the hypothalamohypophyseal control of the reproductive system. Ann. Biol. anim. Bioch. Biophys., 16, 279-289.

MCNATTY K. P., HUNTER W. M., MCNEILLY A. S., SAWERS R. S. 1975. Changes in the concentration of pituitary and steroid hormones in the follicular fluid of human Graafian follicles throughout the menstrual cycle. J. Endocrinol., 64, 555-571.

MOLL J., MEIJS-ROELOFS H. M. A., KRAMER P., DULLAART J., 1976. Effects of electrical stimulation and of direct current and high frequency lesions of the hypothalamus on gonadotrophin release and puberty in female rats. Ann. Biol. anim., Bioch. Biophys., 16, 433-441.

PETERS H., 1979. The human ovary in childhood and early maturity. Europ. J. Obstet. Gynaecol. Reprod. Biol., 9, 137-144.

PETERS H., HIMELSTEIN-BRAW R., FABER M., 1976. The normal development of the ovary in childhood. Acta endocrinol., 82, 617-630.

WINTER J. S. D., FAIMAN C., REYES F. I., HOBSON W. C., 1978 . Gonadofrophins and steroid hormones in the blood and urine of prepubertal girls and other primates. Clin. Endocrinol. Metabol., 7, 513-530. 